\title{
Effect of ghrelin and anamorelin (ONO-7643), a selective ghrelin receptor agonist, on tumor growth in a lung cancer mouse xenograft model
}

\author{
R. Northrup • K. Kuroda • E. Manning Duus • \\ S. Routt Barnes • L. Cheatham • T. Wiley • C. Pietra
}

Received: 27 September 2012 / Accepted: 25 March 2013 / Published online: 12 April 2013

(C) The Author(s) 2013. This article is published with open access at Springerlink.com

\begin{abstract}
Purpose Anamorelin (ONO-7643) is an orally active ghrelin receptor agonist in development for non-small cell lung cancer (NSCLC)-related anorexia/cachexia. It displays both orexigenic and anabolic properties via ghrelin mimetic activity and transient increases in growth hormone (GH). However, increasing GH and insulin-like growth factor-1 in cancer patients raises concerns of potentially stimulating tumor growth. Therefore, we investigated the effect of ghrelin and anamorelin on tumor growth in a murine NSCLC xenograft model.

Methods Female nude mice (15-21/group) with established A549 tumors were administered ghrelin ( $2 \mathrm{mg} / \mathrm{kg}$ i.p.), anamorelin (3,10, or $30 \mathrm{mg} / \mathrm{kg}$ p.o.), or vehicle controls daily for 28 days. Tumor growth, food consumption, and
\end{abstract}

This paper was presented as a poster at the MASCC/ISOO 2012

International Symposium on Supportive Care in Cancer in New York City on 28-30 June 2012.

R. Northrup · E. M. Duus

Research and Development, Helsinn Therapeutics (U.S.), Inc.,

Bridgewater, NJ, USA

K. Kuroda

Safety Research Laboratories, Ono Pharmaceutical, Fukui, Japan

S. R. Barnes $\cdot$ L. Cheatham $\cdot$ T. Wiley

Charles River Discovery Research Services, Morrisville, NC, USA

C. Pietra

Research and Preclinical Development, Helsinn Healthcare, Lugano, Switzerland

R. Northrup $(\square)$

Safety Assessment, Helsinn Therapeutics (U.S.), Inc., 1140 US

Highway 22, Suite 101,

Bridgewater, NJ 08807, USA

e-mail: rnorthrup@helsinnthera.com body weight were monitored. Murine growth hormone $(\mathrm{mGH})$ and murine insulin-like growth factor-1 (mIGF-1) were measured in plasma.

Results Tumor growth progressed throughout the study, with no significant differences between treatment groups. Daily food consumption was also relatively unchanged, while the percentage of mean body weight gain at the end of treatment was significantly increased in animals administered 10 and $30 \mathrm{mg} / \mathrm{kg}$ compared with controls $(p<0.01)$. Peak mGH levels were significantly higher in ghrelin- and anamorelin-treated animals than in controls, while peak mIGF-1 levels were slightly elevated but not statistically significant. All regimens were well tolerated.

Conclusions These findings demonstrate that neither anamorelin nor ghrelin promoted tumor growth in this model, despite increased levels of $\mathrm{mGH}$ and a trend of increased mIGF-1. Together with anamorelin's ability to increase body weight, these results support the clinical development of ghrelin receptor agonist treatments for managing NSCLCrelated anorexia/cachexia.

Keywords Anamorelin · Cachexia · Ghrelin · Growth hormone $\cdot$ IGF-1 $\cdot$ Non-small cell lung cancer

\section{Introduction}

Many patients with advanced stage malignancies often develop cachexia. This multifactorial syndrome is associated with both metabolic and endocrine-related effects. Cachexia is characterized by a $\geq 5 \%$ weight loss, and other symptoms including loss of appetite, energy, muscle mass/strength, and functional performance $[1,2]$. Cachexia can adversely affect a patients' quality of life, their response to therapy, and their survival [3-6]. 
Ghrelin is a 28-amino acid peptide which acts as the endogenous ligand for the ghrelin receptor (GRLN receptor, formally known as GHS-R1a) [7]. Administration of ghrelin to animals and humans has been shown to stimulate gastric acid secretion and motility, increase food intake and appetite leading to weight gain, promote anabolic activity, and inhibit production of pro-inflammatory cytokines, and thus may provide a viable target for cancer-related cachexia [8-11]. Ghrelin activity is thought to be mediated by both growth hormone (GH)-dependent and GH-independent mechanisms [8]. However, the short half-life ( $\sim 30 \mathrm{~min})$, and parenteral administration requirement of ghrelin has limited its clinical usefulness, and interest has switched to the development of orally available ghrelin mimetics [9-11]. One of these, anamorelin (ONO-7643, formally known as RC-1291), is a GRLN receptor agonist currently in development for the treatment of non-small-cell lung cancer (NSCLC)-related anorexia and cachexia. Through its ghrelin and GH-releasing activity, anamorelin has both orexigenic and anabolic properties. Anamorelin has been investigated in healthy volunteers and in cancer patients, where it was associated with significant increases in body weight (BW), total and lean body mass, and handgrip strength and improvements in patient-reported symptoms/quality of life assessments. These clinical studies have also shown increases in plasma levels of $\mathrm{GH}$, insulin-like growth factor-1 (IGF-1), and insulin-like growth factor-binding protein 3 (IGFBP-3) [12-15].

There are conflicting data in the literature regarding the role of ghrelin, GH, and IGF-1 in carcinogenesis. Concerns have been raised that administration of GRLN receptor agonists to cancer patients may potentially stimulate tumor growth. For example, elevated levels of circulating IGF-1 have been observed in cancer patients with certain types of cancers [16]; however, these increased levels may have originated within the tumor itself, therefore representing a consequence rather than a cause of the tumor [17]. There have also been conflicting reports on the effects of ghrelin and other GH-stimulating molecules on the growth of tumor cells in vitro (both enhancing and inhibiting tumor cell proliferation and survival). These inconsistencies may be due in part to varying expression of the GRLN receptor, differences between endocrine and non-endocrine tumor cell lines, and variations in testing methods and concentrations of test agents $[18,19]$. Moreover, there have been reports indicating the therapeutic potential of the major binding protein, IGFBP-3, in attenuating oncogenic behavior either via its ability to bind IGF-1 or via direct, IGF-independent actions [20].

This study was designed to evaluate effects on the growth of A549 NSCLC xenographs in mice administered ghrelin or anamorelin for 28 consecutive days. The plasma levels of GH and IGF-1 were closely monitored in these animals, and potential effects on body weight gain and food consumptions were also measured.

\section{Materials and methods}

Test agents

Ghrelin (Bachem Americas, Inc. Cat \# H-4862, rat/mouse ghrelin) was freshly prepared from pre-weighed vials by dissolving the contents to a concentration of $0.2 \mathrm{mg} / \mathrm{mL}$ in saline solution. Anamorelin hydrochloride salt $(\mathrm{HCl})(\mathrm{ONO}-$ 7643; Helsinn, USA) was formulated in de-ionized (DI) water to a concentration of $3.202(3 \mathrm{mg} / \mathrm{mL}$ free base equivalent) and stored at ambient temperature until use. Additional dosing solutions at $1.07(1.003 \mathrm{mg} / \mathrm{mL}$ free base equivalent) and at $0.32(0.3 \mathrm{mg} / \mathrm{mL}$ free base equivalent $)$ were prepared every 2 weeks by diluting aliquots of the preformulated stock solution with DI water.

\section{Mice}

Nine- to ten-week-old female athymic nude mice $(n u / n u$, Harlan) with BW ranging from 18.4 to $26.6 \mathrm{~g}$ were housed on irradiated bedding in static microisolators under controlled temperature $\left(21-22{ }^{\circ} \mathrm{C}\right)$, humidity $(40-60 \%)$, and light/dark cycle $(12 \mathrm{~h})$. The animals were given ad libitum water (reverse osmosis, $1 \mathrm{ppm} \mathrm{Cl}$ ) and NIH 31 Modified and Irradiated Lab Diet ${ }^{\circledR}$ consisting of $18 \%$ crude protein, $5 \%$ crude fat, and $5 \%$ crude fiber. All experimental procedures for animal care and housing were undertaken in an animal care facility accredited by the Association for Assessment and Accreditation of Laboratory Animal Care International and according to the requirements stated in the ILAR Guide for the Care and Use of Laboratory Animals [21].

\section{Tumor cell culture and implantation}

A549 NSCLC tumor cells were grown to mid-log phase in Kaighn's modified Ham's F12 medium supplemented with $10 \%$ fetal bovine serum, 100 units $/ \mathrm{mL}$ penicillin $\mathrm{G}$, $100 \mu \mathrm{g} / \mathrm{mL}$ streptomycin sulfate, $25 \mu \mathrm{g} / \mathrm{mL}$ gentamicin, $2 \mathrm{mM}$ glutamine, and $1 \mathrm{mM}$ sodium pyruvate. Cell cultures were incubated at $37{ }^{\circ} \mathrm{C}$ with $5 \% \mathrm{CO}_{2}$ in a humidified atmosphere.

A549 tumor cells used for implantation were harvested during log phase growth and re-suspended in $50 \%$ Matrigel matrix (BD Biosciences) at $5 \times 10^{7}$ cells $/ \mathrm{mL}$. Mice were injected subcutaneously in the right flank with a $0.2 \mathrm{~mL}$ suspension $\left(1 \times 10^{7}\right.$ cells/mouse $)$.

Treatment study design

In the treatment study (Fig. 1), implanted tumors were monitored as their volumes approached $150-250 \mathrm{~mm}^{3}$. Twenty-one days post-implant (study day 1), mice were randomized into six groups of 15 mice each with individual 
Fig. 1 Study design

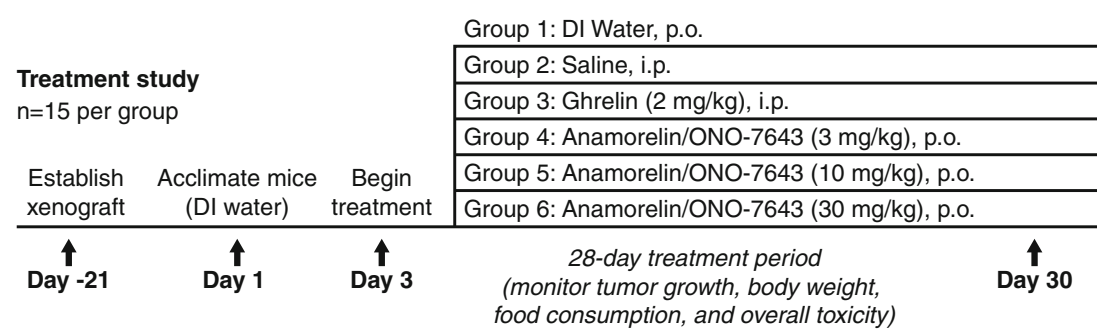

Sampling study

$\mathrm{n}=21$ per group

\begin{tabular}{|c|c|c|c|c|}
\hline & \multirow{3}{*}{$\begin{array}{l}\text { Acclimate mice } \\
\text { (DI water) }\end{array}$} & \multirow{3}{*}{$\begin{array}{l}\text { Begin } \\
\text { treatment }\end{array}$} & \multicolumn{2}{|l|}{ Group 1: DI vater, p.o. } \\
\hline & & & Group 2: Ghrelin (2 mg/kg), i.p. & \\
\hline & & & Group 3: Anamorelin/ONO-7643 (30 mg/kg), p.o. & \\
\hline $\begin{array}{c}\begin{array}{l}\text { Establish } \\
\text { xenograft }\end{array} \\
\end{array}$ & Day 1 & $\begin{array}{c}\text { † } \\
\text { Day } 3\end{array}$ & \multicolumn{2}{|l|}{$\begin{array}{l}\text { 28-day treatment period } \\
\text { (measure mIGF-1 and mGH, }\end{array}$} \\
\hline
\end{tabular}

tumor volumes ranging from 144 to $221 \mathrm{~mm}^{3}$ and group mean tumor volumes of $180 \mathrm{~mm}^{3}$. Tumor volume in cubic millimeters was calculated using the following formula: tumor volume $=($ length $\times$ square of the width $) \div 2$. Mice were acclimatized to dosing by administering DI water orally (p.o.) on days 1 and 2, before beginning treatment on day 3 . In all groups, the dosing volume of $10 \mathrm{~mL} / \mathrm{kg}$ was scaled according to the weight of each individual animal. From day 3 to day 30 (28-day treatment period), group 1 received DI water p.o., group 2 received saline intraperitoneally (i.p.), group 3 received ghrelin once daily at $2 \mathrm{mg} / \mathrm{kg}$ i.p., and groups 4-6 received anamorelin $\mathrm{HCl}$ once daily at 3,10 , or $30 \mathrm{mg} / \mathrm{kg}$ p.o.

Sampling study design

In the sampling study (Fig. 1), mice with implanted tumors were monitored until 21 days post-implant (study day 1) and randomized into three groups of 21 mice each with individual BW ranging from 19.1 to $26.3 \mathrm{~g}$ and a group mean of 22.7-23.0 g. Acclimatizing with DI water and scaling dosing volume followed the same procedures as for the treatment study. In the sampling study, from days 3 to 30 (28-day treatment period), group 1 received DI water p.o., group 2 received ghrelin once daily at $2 \mathrm{mg} / \mathrm{kg}$ i.p., and group 3 received anamorelin $\mathrm{HCl}$ once daily at $30 \mathrm{mg} / \mathrm{kg}$ p.o.

\section{Endpoints}

In the treatment study, tumor volumes were measured twiceweekly until study completion on day 30, and mean tumor volumes and median tumor volumes (MTV) were calculated for each group. Tumor growth inhibition (TGI) was calculated for each group according to the following formula: \%TGI $=\left[\left(\mathrm{MTV}_{\text {control }}-\mathrm{MTV}_{\text {treated }}\right) \div \mathrm{MTV}_{\text {control }}\right] \times 100$. Food consumption was measured daily, with mean daily food consumption calculated as the difference between the food weight before and after the feeding period for each group. Animals were weighed daily, and the mean BW on days 3, 15, and 30 were calculated. Percentage change in BW from days 3 to 30 was determined for each group.

In the sampling study, whole blood samples from three animals in each group were obtained by retro-orbital bleed under isoflurane anesthesia into ethylenediaminetetraacetic acid-coated tubes. Samples were taken prior to the first dose and at 5, 15, 30, 60, 180, and $360 \mathrm{~min}$ after the first and last doses of DI water, ghrelin $2 \mathrm{mg} / \mathrm{kg}$, and anamorelin $30 \mathrm{mg} / \mathrm{kg}$. Murine insulin-like growth factor-1 (mIGF-1) and murine growth hormone $(\mathrm{mGH})$ were assessed from plasma samples using commercially available enzymelinked immunosorbent assay (ELISA) kits. Assays with rat/mouse IGF-1 ELISA kits (Immunodiagnostic Systems, Cat. No. AC-18 F1) and rat/mouse GH ELISA kits (Millipore Corporation, Cat. No. EZRMGH-45 K) were performed as per manufacturer's instructions. Results were expressed as means \pm standard error of the mean.

\section{Toxicity}

In both studies, mice were observed frequently for signs of any adverse treatment-related side effects, and clinical signs of toxicity were recorded. Acceptable toxicity for the maximum tolerated dose was defined as a group mean BW loss of less than $20 \%$ and not more than $10 \%$ treatment-related mortality. Relationship to treatment was determined by signs and/or necropsy, or due to unknown causes during the dosing period.

\section{Statistical analysis}

Data analysis was performed using Prism software, version 3.03 (GraphPad). Statistical analyses of the differences between the median tumor burdens and percentage change in $\mathrm{BW}$ in control and treated groups were calculated using the Kruskal-Wallis or Mann-Whitney $U$ test. Differences in 
BW and cumulative food consumption for each group compared with control were assessed using one-way analysis of variance or unpaired $t$ test. All analyses were assessed at a significance level of 0.05 .

\section{Results}

Effects of ghrelin and anamorelin on tumor growth in vivo

Tumor growth progressed steadily over time in all groups, with no statistically significant differences between the ghrelin- and anamorelin-treated animals and their respective controls (Fig. 2). Animals administered anamorelin at $10 \mathrm{mg} / \mathrm{kg}$, but not $30 \mathrm{mg} / \mathrm{kg}$, had a delay in their median tumor growth curve compared with their control group, therefore, this difference was not drug-related.

Day $30 \mathrm{MTV}$ and percentage TGI data are presented in Table 1.

Effects of ghrelin and anamorelin on food consumption and body weight

Median daily food consumption was similar in all groups, unchanged over the course of the study, and without any statistically significant difference between groups (Fig. 3). Animals administered $30 \mathrm{mg} / \mathrm{kg}$ of anamorelin showed a trend of increased food intake compared with their controls, but the increase was not statistically significant.

Figure 4 shows the percentage change in mean BW over time. In animals administered ghrelin $2 \mathrm{mg} / \mathrm{kg}$, the percentage change in mean BW from days 1 to 30 was greater compared with the saline control group $(13.7 \% \pm 1.55$ versus $10.5 \% \pm$ 1.04 , respectively). However, this difference was not statistically significant. Over the treatment period, animals administered anamorelin at 10 and $30 \mathrm{mg} / \mathrm{kg} /$ day showed a statistically significant increase in their percentage of mean BW (11.7 \% \pm 1.26 and $14.4 \% \pm 1.08$, respectively) compared with controls $(7.6 \% \pm 0.99 ; p<0.01$ versus $10 \mathrm{mg} / \mathrm{kg}$ and $p<0.001$ versus $30 \mathrm{mg} / \mathrm{kg}$ ). Mice administered $3 \mathrm{mg} / \mathrm{kg}$
Table 1 Tumor growth inhibition on day 30

\begin{tabular}{llll}
\hline $\begin{array}{l}\text { Treatment } \\
\text { group }\end{array}$ & $\begin{array}{l}\text { MTV, } \\
\mathrm{mm}^{3}\end{array}$ & $\begin{array}{l}\% \\
\text { TGI }\end{array}$ & $\begin{array}{l}\text { Individual } \\
\text { tumor volume } \\
\text { range }^{\mathrm{a}}, \mathrm{mm}^{3}\end{array}$ \\
\hline 1: DI water p.o. & 1,008 & - & $446-1,666$ \\
2: Saline i.p. & 968 & - & $221-2,025$ \\
3: Ghrelin i.p. $2 \mathrm{mg} / \mathrm{kg}$ & 936 & 3 & $256-1,688$ \\
4: Anamorelin p.o. $3 \mathrm{mg} / \mathrm{kg}$ & 1,080 & -7 & $245-2,176$ \\
5: Anamorelin p.o. $10 \mathrm{mg} / \mathrm{kg}$ & 666 & 34 & $126-1,666$ \\
6: Anamorelin p.o. $30 \mathrm{mg} / \mathrm{kg}$ & 847 & 16 & $320-2,432$ \\
\hline
\end{tabular}

$D I$ deionized, i.p. intraperitoneal, MTV median tumor volume, p.o. oral, TGI tumor growth inhibition

DI water (group 1) is the designated control group for groups 4-6; saline (group 2) is the designated control group for group 3. Comparisons of treatment groups versus their respective controls were not statistically significant $(p>0.05)$

${ }^{\mathrm{a}}$ Range $=$ minimum - maximum for the 15 individual animals per treatment group

anamorelin did not show a statistically significant increase in BW compared with control animals $(9.1 \% \pm 0.97 ; p>0.05)$.

Effects of ghrelin and anamorelin on plasma levels of mIGF-1 and $\mathrm{mGH}$

Compared with the vehicle control, peak plasma levels of mIGF-1 were higher in animals administered ghrelin $2 \mathrm{mg} / \mathrm{kg}$ and anamorelin $30 \mathrm{mg} / \mathrm{kg}$ compared with controls, but this difference was not statistically significant (Fig. 5a). The plasma levels of mIGF-1 in response to DI water and ghrelin exhibited peak values of $554 \pm 25.13$ and $647.1 \pm 11.63 \mathrm{ng} / \mathrm{mL}$, respectively, at $15 \mathrm{~min}$ after the last dose. The plasma levels of mIGF-1 in response to anamorelin exhibited peak values of $713.2 \pm 50.08 \mathrm{ng} / \mathrm{mL}$ at $5 \mathrm{~min}$ after the last dose.

Peak plasma levels of mGH in animals administered anamorelin $30 \mathrm{mg} / \mathrm{kg}$ and ghrelin $2 \mathrm{mg} / \mathrm{kg}$ were greater than the controls at 5-30 min after the last dose (Fig. 5b). The plasma levels of $\mathrm{mGH}$ in response to DI water exhibited peak values of $21.4 \pm 6.53 \mathrm{ng} / \mathrm{mL}$ at $15 \mathrm{~min}$ after the last
Fig. 2 Effect of treatment on median tumor volume over time

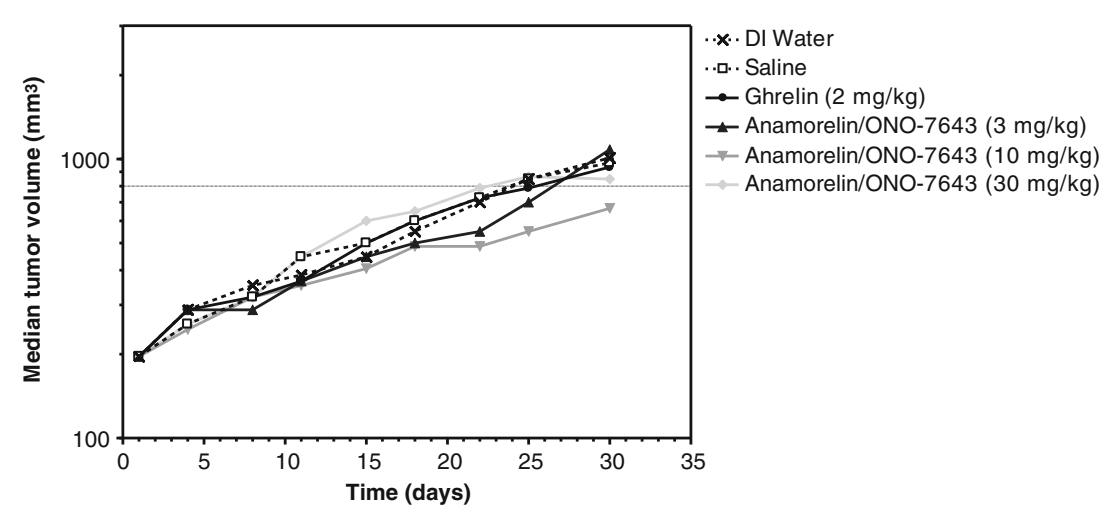


Fig. 3 Effect of treatment on median daily feed consumption over time

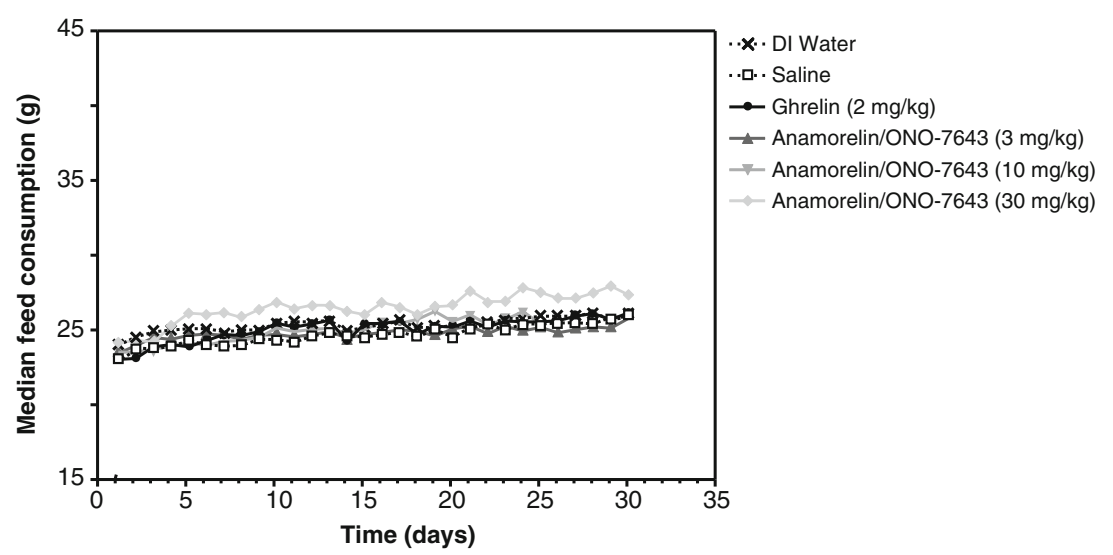

dose. The plasma levels of $\mathrm{mGH}$ in response to ghrelin peaked at $1,318.9 \pm 173.59 \mathrm{ng} / \mathrm{mL}$ at $15 \mathrm{~min}$ after the last dose, and the plasma level of $\mathrm{mGH}$ in response to anamorelin peaked at $64.9 \pm 12.73 \mathrm{ng} / \mathrm{mL}$ at $15 \mathrm{~min}$ after the last dose.

\section{Toxicity}

There were no signs of drug-related toxicity and no treatmentrelated deaths.

\section{Discussion}

In this study, our primary objectives were to evaluate the effects of anamorelin or ghrelin treatment on the growth of A549 NSCLC xenografts and to measure GH and IGF-1 plasma concentrations. Additional objectives included the effects of daily treatment with ghrelin or anamorelin on food consumption, BW changes, and potential toxicity in this model.

Overall, our results show that all regimens were well tolerated with no treatment-related deaths and no observations indicative of treatment-related side effects. Most importantly, neither ghrelin nor anamorelin treatment for 28 days affected tumor growth in tumor-bearing nude mice, despite significantly increased peak mGH levels and slight elevations in peak mIGF-1 levels. Specifically, anamorelin stimulated a maximum increase in GH concentrations by up to $\sim 2.5$-fold after repeated administration, which is similar to previously published data with MK677 (another GRLN receptor agonist) in dogs [22], while repeated dosing with ghrelin in this study resulted in a maximum increase in $\mathrm{GH}$ concentrations of approximately 50 fold. For IGF-1, the average mean concentration after the last dose of anamorelin was increased up to $122 \%$ of the vehicletreated animals, and ghrelin's post-last-dose IGF-1 concentration was $109 \%$ of the vehicle-treated animals.

The finding in our study that ghrelin and anamorelin do not promote tumor growth, even in the presence of elevated GH and IGF-1, is consistent with findings from other studies evaluating GH-based therapies in tumor-bearing animals [9, 23-26], as well as in formal carcinogenicity studies in tumor-free animals [27], as summarized below.

In a study by Khan et al. [9], treatment with a GHreleasing hormone (GHRH)-expressing plasmid in nude mice implanted with a human bronchioalveolar carcinoma cell line did not increase the growth of the tumor, but rather it reduced tumor volume by $40 \%$, suggesting that the therapeutic role of GH-based therapies may not be limited to cachexia. Similarly, constitutive expression of GHRH in an immunocompetent animal model led to a decrease in tumor growth rate and additionally reduced the likelihood of metastasis [23], whereas immunocompetent mice pretreated with an analog of MK677 resisted subsequent tumor
Fig. 4 Effect of treatment on percentage change in mean body weight over time. Error bars have been omitted for clarity

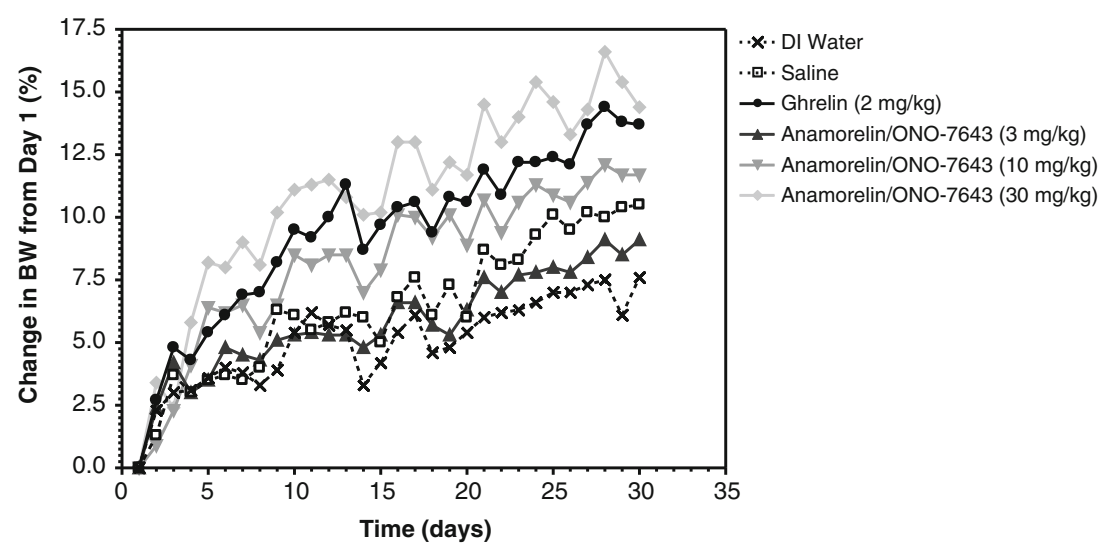




$$
\begin{aligned}
& \therefore \times \text {. DI Water } \\
& \rightarrow \text { - Ghrelin }(2 \mathrm{mg} / \mathrm{kg}) \\
& \rightarrow-\text { Anamorelin/ONO-7643 (30 mg/kg) }
\end{aligned}
$$
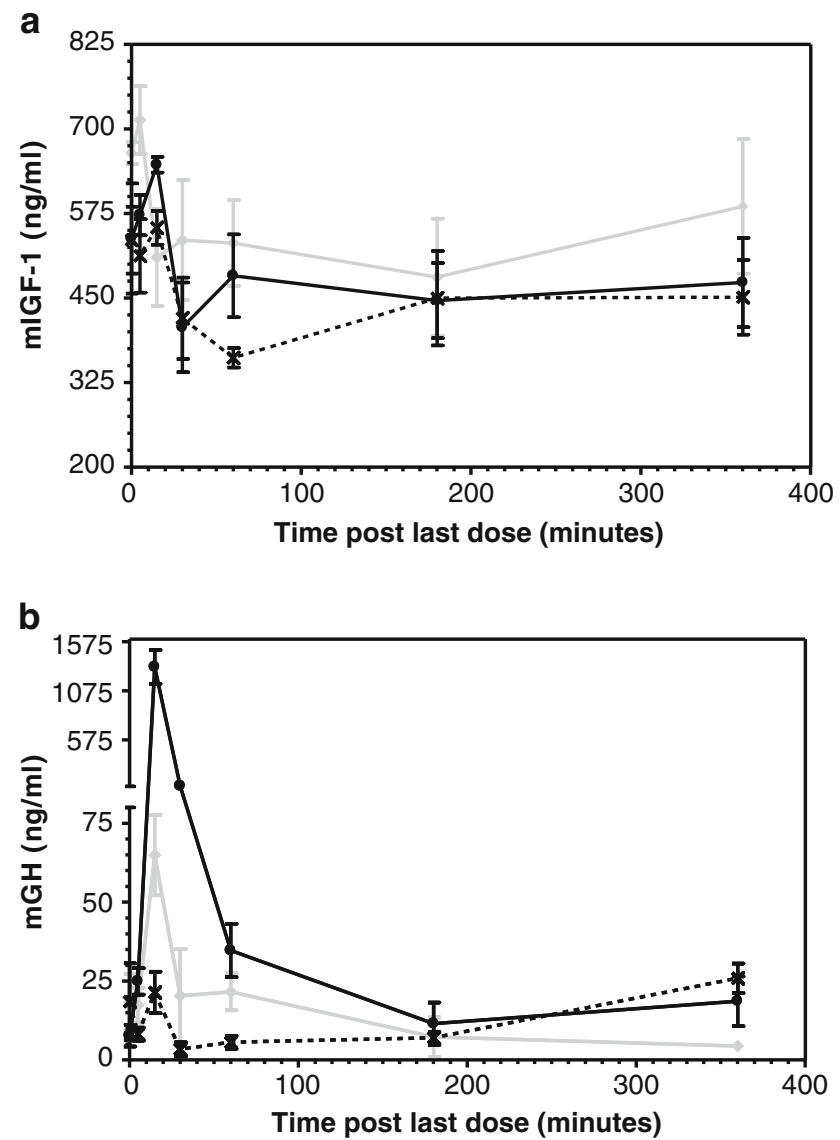

Fig. 5 Plasma levels of mIGF-1 (a) and mGH (b) after the last dose

initiation [24]. Perboni et al. demonstrated that the addition of the ghrelin agonist growth hormone releasing peptide-2 (GHRP-2) to cytotoxic therapy with 5-fluorouracil (5-FU) prevented the anorexia associated with chemotherapy in tumor-bearing cachectic BALB/c mice, and there was also a trend of improved survival in the 5-FU+GHRP-2 treated mice compared with those with 5-FU alone [25]. Infusion of a ghrelin analog (BIM-28131) or human ghrelin in a rat sarcoma model also demonstrated beneficial anti-cachexia effects (improved food consumption, BW, and retention of lean body mass), and there was no increase in tumor mass after treatment [26]. In terms of GH safety in tumor-free animals, Farris et al. conducted a formal 2-year bioassay in rats and mice to investigate the carcinogenic potential of each biologically active GH in the respective species [27]. Recombinant rat and mouse $\mathrm{GH}$ administration resulted in systemic GH exposures of approximately 10 -fold over basal levels. Even in the presence of these elevated GH levels, there were no increases in incidence or spectrum of neoplastic changes in either species, and there was a favorable effect on longevity. There were also no treatment-related physical signs noted in either species or gender, and all doses were well tolerated [27].

There is also experimental evidence in cancer cachexia that suggests IGF-1 might be beneficial rather than harmful. For example, in rats bearing the AH-130 hepatoma, a wellcharacterized model of cachexia, the expression of IGF-1 in liver and skeletal muscle was shown to be reduced compared with controls [28]. Furthermore, in the Yoshida hepatoma rat model, Schmidt et al. showed that low-dose IGF-1 supplementation had no effect on tumor growth and actually reduced mortality. Moreover, there was an attenuated loss of BW and muscle mass, and an improved quality of life was observed in IGF-1-treated animals [29]. These data highlight the need for more studies to elucidate the interactions of IGF-1 on tumor growth and on cancer-related cachexia.

From a clinical perspective, data obtained to-date with anamorelin also support the safety profile in human cancer patients. For example, in a Phase II study with over 80 patients with different tumor types, there was no difference in the incidence of adverse events of "disease progression" between patients receiving placebo or anamorelin for up to 12 weeks [15]. Currently, anamorelin is being evaluated in two Phase III clinical trials in cachectic patients with advanced NSCLC (NCT01387269 and NCT01387282), and the 12-week safety extension study (NCT01395914) may provide additional support of the long-term safety of anamorelin in cancer patients.

In conclusion, the findings from this study support the development of GRLN receptor agonist treatments for the management of NSCLC-related anorexia/cachexia. Importantly, neither ghrelin nor anamorelin promoted tumor growth in this murine xenograft model, and anamorelin also demonstrated its ability to significantly increase BW. Additional studies in other experimental tumor models, as well as evaluations of IGFBP-3 levels, may help to further understand the interactions between ghrelin, ghrelin mimetics, and the additional effects of increased GH and IGF-1 plasma levels on the growth of tumor cells in vivo.

Acknowledgments This study was co-sponsored by Helsinn and Ono Pharmaceutical Co., Ltd, and conducted at Charles River Discovery Research Services, Morrisville, NC, USA (Piedmont Research Center). The authors would like to acknowledge Alan Meshaw for his contribution to statistical analysis. Editorial assistance was provided by Elena Palmesino (Helsinn Healthcare, Lugano, Switzerland) and Sandra Mendes (TRM Oncology, The Hague, The Netherlands), funded by Helsinn.

Conflicts of interest Robert Northrup and Elizabeth Manning Duus are employees of Helsinn Therapeutics (U.S.), Inc, and Claudio Pietra is an employee of Helsinn Healthcare. Ken Kuroda was an employee of Ono Pharmaceuticals. Sheri Routt Barnes, Lynn Cheatham, and Tim Wiley are employees of Charles River Discovery Research Services, a company which was paid by Helsinn and Ono to conduct this study. The authors have full control of the primary data and agree to allow the journal to review their data if requested. 
Open Access This article is distributed under the terms of the Creative Commons Attribution Noncommercial License which permits any noncommercial use, distribution, and reproduction in any medium, provided the original author(s) and the source are credited.

\section{References}

1. Tisdale MJ (2002) Cachexia in cancer patients. Nat Rev Cancer 2:862-871

2. Fearon K, Strasser F, Anker SD, Bosaeus I, Bruera E, Fainsinger RL, Jatoi A, Loprinzi C, Macdonald N, Mantovani G, Davis M, Muscaritoli M, Ottery F, Radbruch L, Ravasco P, Walsh D, Wilcock A, Kaasa S, Baracos VE (2011) Definition and classification of cancer cachexia: an international consensus. Lancet Oncol 12:489-495

3. Arrieta O, Michel Ortega RM, Villanueva-Rodríguez G, SernaThomé MG, Flores-Estrada D, Diaz-Romero C, Rodríguez CM, Martínez L, Sánchez-Lara K (2010) Association of nutritional status and serum albumin levels with development of toxicity in patients with advanced non-small cell lung cancer treated with paclitaxelcisplatin chemotherapy: a prospective study. BMC Cancer 10:50

4. Dewys WD, Begg C, Lavin PT, Band PR, Bennett JM, Bertino JR, Cohen MH, Douglass HO Jr, Engstrom PF, Ezdinli EZ, Horton J, Johnson GJ, Moertel CG, Oken MM, Perlia C, Rosenbaum C, Silverstein MN, Skeel RT, Sponzo RW, Tormey DC (1980) Prognostic effect of weight loss prior to chemotherapy in cancer patients. Eastern Cooperative Oncology Group. Am J Med 69:491-497

5. Reid J, McKenna H, Fitzsimons D, McCance T (2009) The experience of cancer cachexia: a qualitative study of advanced cancer patients and their family members. Int J Nurs Stud 46:606-616

6. McClement S (2005) Cancer anorexia-cachexia syndrome: psychological effect on the patient and family. J Wound Ostomy Continence Nurs 32:264-268

7. Davenport AP, Bonner TI, Foord SM, Harmar AJ, Neubig RR, Pin JP, Spedding M, Kojima M, Kangawa K (2005) International Union of Pharmacology. LVI. Ghrelin receptor nomenclature, distribution, and function. Pharmacol Rev 57:541-546

8. Akamizu T, Kangawa K (2010) Ghrelin for cachexia. J Cachex Sarcopenia Muscle 1:169-176

9. Khan AS, Smith LC, Anscombe IW, Cummings KK, Pope MA, Draghia-Akli R (2005) Growth hormone releasing hormone plasmid supplementation, a potential treatment for cancer cachexia, does not increase tumor growth in nude mice. Cancer Gene Ther 12:54-60

10. Strasser F, Lutz TA, Maeder MT, Thuerlimann B, Bueche D, Tschöp M, Kaufmann K, Holst B, Brändle M, von Moos R, Demmer R, Cerny T (2008) Safety, tolerability and pharmacokinetics of intravenous ghrelin for cancer-related anorexia/cachexia: a randomised, placebo-controlled, doubleblind, double-crossover study. Br J Cancer 98:300-308

11. Kim HJ, Kim HJ, Yun J, Kim KH, Kim SH, Lee SC, Bae SB, Kim CK, Lee NS, Lee KT, Park SK, Won JH, Park HS, Hong DS (2012) Pathophysiological role of hormones and cytokines in cancer cachexia. J Korean Med Sci 27:128-134

12. Garcia JM, Polvino WJ (2007) Effect on body weight and safety of RC-1291, a novel, orally available ghrelin mimetic and growth hormone secretagogue: results of a phase I, randomized, placebocontrolled, multiple-dose study in healthy volunteers. Oncologist 12:594-600

13. Garcia JM, Polvino WJ (2009) Pharmacodynamic hormonal effects of anamorelin, a novel oral ghrelin mimetic and growth hormone secretagogue in healthy volunteers. Growth Horm IGF Res 19:267-273

14. Garcia JM, Friend J, Allen S (2012) Therapeutic potential of anamorelin, a novel, oral ghrelin mimetic, in patients with cancer-related cachexia: a multicenter, randomized, double-blind, crossover, pilot study. Support Care Cancer 21:129-137

15. Garcia J, Boccia RV, Graham C, Kumor K, Polvino W (2007) A phase II randomized, placebo controlled, double-blind study of the efficacy and safety of RC-1291 (RC) for the treatment of cancer cachexia [abstract]. American Society of Clinical Oncology (ASCO) annual meeting. J Clin Oncol 25:9133

16. Jenkins PJ, Bustin SA (2004) Evidence for a link between IGF-I and cancer. Eur J Endocrinol 151(Suppl 1):S17-S22

17. Shariat SF, Lamb DJ, Kattan MW, Nguyen C, Kim J, Beck J, Wheeler TM, Slawin KM (2002) Association of preoperative plasma levels of insulin-like growth factor I and insulin-like growth factor binding proteins- 2 and -3 with prostate cancer invasion, progression, and metastasis. J Clin Oncol 20:833-841

18. Nikolopoulos D, Theocharis S, Kouraklis G (2010) Ghrelin: a potential therapeutic target for cancer. Regul Pept 163:7-17

19. Chopin L, Walpole C, Seim I, Cunningham P, Murray R, Whiteside E, Josh P, Herington A (2011) Ghrelin and cancer. Mol Cell Endocrinol 340:65-69

20. Baxter RC (2001) Signalling pathways involved in antiproliferative effects of IGFBP-3: a review. Mol Pathol 54:145-148

21. National Research Council (1996) Guide for the care and use of laboratory Animals. National Research Council, Washington, D.C

22. Hickey GJ, Jacks TM, Schleim KD, Frazier E, Chen HY, Krupa D, Feeney W, Nargund RP, Patchett AA, Smith RG (1997) Repeat administration of the GH secretagogue MK-0677 increases and maintains elevated IGF-I levels in beagles. J Endocrinol 152:183192

23. Khan AS, Anscombe IW, Cummings KK, Pope MA, Smith LC, Draghia-Akli R (2003) Effects of plasmid-mediated growth hormone-releasing hormone supplementation on LL-2 adenocarcinoma in mice. Mol Ther 8:459-466

24. Koo GC, Huang C, Camacho R, Trainor C, Blake JT, SirotinaMeisher A, Schleim KD, Wu TJ, Cheng K, Nargund R, McKissick $\mathrm{G}$ (2001) Immune enhancing effect of a growth hormone secretagogue. J Immunol 166:4195-4201

25. Perboni S, Bowers C, Kojima S, Asakawa A, Inui A (2008) Growth hormone releasing peptide 2 reverses anorexia associated with chemotherapy with 5-fluorouracil in colon cancer cell-bearing mice. World J Gastroenterol 14:6303-6305

26. DeBoer MD, Zhu XX, Levasseur P, Meguid MM, Suzuki S, Inui A, Taylor JE, Halem HA, Dong JZ, Datta R, Culler MD, Marks DL (2007) Ghrelin treatment causes increased food intake and retention of lean body mass in a rat model of cancer cachexia. Endocrinology 148:3004-3012

27. Farris GM, Miller GK, Wollenberg GK, Molon-Noblot S, Chan C, Prahalada S (2007) Recombinant rat and mouse growth hormones: risk assessment of carcinogenic potential in 2-year bioassays in rats and mice. Toxicol Sci 97:548-561

28. Costelli P, Muscaritoli M, Bossola M, Penna F, Reffo P, Bonetto A, Busquets S, Bonelli G, Lopez-Soriano FJ, Doglietto GB, Argilés JM, Baccino FM, Rossi Fanelli F (2006) IGF-1 is downregulated in experimental cancer cachexia. Am J Physiol Regul Integr Comp Physiol 291:R674-R683

29. Schmidt K, von Haehling S, Doehner W, Palus S, Anker SD, Springer J (2011) IGF-1 treatment reduces weight loss and improves outcome in a rat model of cancer cachexia. J Cachex Sarcopenia Muscle 2:105-109 